\title{
Survey of the Literature Reading Habits and Preferences of Adolescents: A Study of a Public School in India
}

\author{
Fayaz Ahmad Loan and Refhat-un-nisa Shah \\ Centre of Central Asian Studies \\ University of Kashmir, Srinagar, India \\ fayazlib@yahoo.co.in; refhat003@gmail.com
}

\begin{abstract}
Background. In the modern competitive age, reading is the cornerstone for success in all academic disciplines.

Objectives. The study sought to find out the literature reading habits and preferences of adolescent students, and the promotional tactics of authors to attract these students towards reading.

Methods. The data was collected in the Delhi Public School, Srinagar in India, from students of 11th and 12th classes (grades), aged between 14-16 years. A questionnaire survey was administered to 150 students who were systematically sampled.

Results. The study found that adolescents of both genders like reading (69\% of girls; $65 \%$ of boys) on electronic media. Adolescents have varied tastes in reading. Fiction is the most preferred genre of literature read by respondents, followed by non-fiction. However, girls have a greater preference for fiction compared to boys. Similarly boys have a greater preference for non-fiction compared to girls. Among the various genres of fiction, crime/detective is the most read genre, followed by realistic teen fiction. Romance and poetry are more popular among girls, whereas crime/detective, horror, and realistic teen fiction are more popular among boys. For non-fiction, the respondents generally read selfhelp/personality development books, followed by personalities and historical literature. Boys prefer to read about personalities whereas self-help/personality development is the first preference of girls. To attract adolescents, authors include aggression and violence, romantic language, explicit content (sexuality), and slang/crude language amongst other tactics in their writings (literature).
\end{abstract}

\section{INTRODUCTION}

Reading is a password to success. The reading habit influences the promotion of one's personal development in particular and social progress in general (Shafi \& Loan, 2010). Regular and systematic reading sharpens the intellect, refines the emotions, elevates tastes and provides perspectives for one's living; and thereby prepares a person for an effective participation in the social, religious, cultural and political life (Lone, 2011, April 23). “A dumb person becomes a communicator and a lame climbs mountains of knowledge through reading” (Satija, 2002). Reading fires the imagination of a person, and adds new sight to one's eyes and new wisdom to the mind. Reading loads the mind with new software (Satija, 2002). The individual who reads well has at his command a means for widening his mental horizons 
and for multiplying his opportunities for success. Joseph Addison and Richard Steele (1710/1899) said that "Reading is to the mind what exercise is to the body". According to Gray and Tinker (1967), reading influences the extent and accuracy of information as well as attitudes, morals, beliefs, and judgment of readers. In Democracy and other addresses: Books and libraries, published in 1893, James Russel Lowell (cited by Robinson \& Good, 1987) described the value of extensive reading as follows:

Have you rightly considered what the mere ability to read means? That it is the key which admits us to the whole world of thought and fancy and imagination to the company of the saint and sage, of the wisest and wittiest moment! That it enables us to see with the keenest eyes, hear with the finest ears, and listen to the sweetest voices of all times! (pp. iv)

Salim (2009) observed that reading pleasantly entertains in all weathers and in all fortunes. Elizabeth (2009) spoke about the taste for reading as:

The greatest gift is the passion for reading. It is cheap, it consoles, it distracts, it excites. It gives you knowledge of the world and experience of a wide kind. It is a moral illumination.

The reading habit is the heart of self-education and lifelong learning. In the modern competitive age, reading is the cornerstone for success in all academic disciplines. A good reading habit is a healthy addiction; once this powerful habit is mastered, it improves the vocabulary, analytical skills, concentration power and deciphering new words and thereby helps a student in his academic achievements (Lone, 2011). Next to the teacher, reading is usually the principal educating agency contributing to pupil's success. In the opinion of Loan (2010, p. 15), "Reading is to education what breathing is to life”. Most reading authorities agree that students benefit from time spent reading. Benefits include vocabulary growth (Nagy, Herman, \& Anderson, 1985; Cunningham \& Stanovich, 1998), increased fluency in word recognition (Adams, 1990), gains in comprehension (Taylor, Frye, \& Maruyama, 1990; Cipielewski \& Stanovich, 1992; Guthrie, Wigfield, Metsala, \& Cox, 1999) and oral language abilities (Teale \& Martinez, 1988). Yopp and Yopp (2003) summarized the belief of many professionals in the reading community when they asserted that "Time spent reading is related to growth in vocabulary, fluency in word recognition, and comprehension”.

\section{LITERATURE REVIEW}

Reading has long been the object of empirical and theoretical investigations. Norvell (1973), after conducting a comprehensive study of the reading interests of high school students over a period of twelve years, reported that sex and age are the two principal factors affecting reading habits. Later researchers confirmed that females enjoy reading more than males (McKenna, Kearn, \& Ellsworth, 1995; Clark \& Foster, 2005; Shafi \& Loan, 2010), are more heavy readers than males (Stenberg, 2001; Ross, 2002; Shafi \& Loan, 2010), read more for pleasure than males (McKenna, Kearn, \& Ellsworth, 1995; Moyes, 2000; Hassell \& Rodge, 2007), and spend more time on reading than males (Hopper, 2005). Clark (2012) found that more girls enjoy reading ( $56.7 \%$ compared to $43.8 \%$ for boys), chose to read daily (35.3\% compared to 26.8\%), and expressed more positive opinions about reading than boys. Researchers have also found that younger people are more avid readers than older (Ross, 2002); highly educated more than less educated (Stenberg, 2001), urban students more than rural (Lone, 2011), and privileged social classes more than people of lower socio-economic backgrounds (Clark \& Akerman, 2006). Overall, sex, age, education, regional, social and economic factors affect reading choices. 
Children give credit to many people for developing an interest in reading. Clark and Foster (2005) reported that $83.9 \%$ of pupils indicated their mother as the one who taught them to read, followed by their teacher (72.2\%) and father (65.0\%). Loan (2011a) revealed that students developed the reading habit mostly through self-effort (36.24\%), followed by the help of parents (28.48\%) and teachers (13.17\%). Kendrick (1999) reported that 86\% of the middle-grade boys indicated that their parents didn't read with them. De Boer and Dall Mann (1960) advocated that it is the task of the teacher to bring the child and book together, whereas Shokeen (2005) argued that it is the duty of parents and librarians.

Time spent on reading varies from study to study. Hastings and Henry (2006) found that more than half of students (56\%) spent less than an hour a day, whereas others (e.g., Tella \& Akande, 2007; Loan, 2011a) disclosed that the majority of the students spent between 1-2 hours per day on reading. The Department of Education, Hong Kong (2001) found that students spent two or more hours on reading in a week, whereas Sarjit and Thiyagarajah (1999) found that students spent as much as 3 to 5 hours per week on reading, and Sheorey and Mokhtari (1994) reported that students read an average of 4.75 hours per week. In brief, time, place (e.g., countries) and facilities may affect spending time on reading.

People including students read with different aims. Mellon (1990) and (Cox \& Guthrie, 2001) revealed that the majority of teenagers read for entertainment and enjoyment. On the other hand, Igun and Adogbeji (2007) reported that nearly two-thirds (62\%) of postgraduate students were motivated to read primarily by the desire for knowledge and skills, while $23 \%$ study mainly to pass examinations/tests and for self-development. Cabral and Tavares (2002) reflected that students read for academic purposes (97.8\%) almost as much as they read as a hobby (97.2\%). Loan (2011a) revealed that the students mostly read for education (43.49\%), followed by information (40.23\%), and a much smaller percentage (11.39\%) read for recreation. Shafi and Loan (2010) revealed that religion is the first choice (28.85\%), science and technology, the second (18.93\%), and literature, the third choice for student reading. Devarajan (1989) and Tella and Akande (2007) reported that reading literature, especially novels, is most students' first choice. Abdul Karim and Hasan (2007) concluded that university students spent more time reading academic texts instead of fiction or non- fiction. Wicks (1995) confirmed that reading fiction was preferred over non-fiction among boys aged 13-15 years. Vakkari and Serola (2012) surveyed 1000 Finnish adolescents and adults, and found that the participants used libraries to read fiction (70\%), to read non-fiction (67\%) and for self-education (59\%) during their leisure time. Walia and Sinha (2014) reported that fiction was the "most preferred" type of literature (41.7\%), followed by non-fiction (34.1\%). Among the "most preferred" genres of fiction, thrillers (35.9\%), horror (22.4\%) and romance (18.4\%) topped the list, whereas in the non-fiction category, among the "most preferred" genre, comics (17\%), general knowledge (15.7\%) and philosophy (14.8\%) topped the list. Tveit (2012) found that boys were more interested in non-fiction books (28\%) compared to girls (14\%). The girls listed young adult novels and serial books, with brave but emotional heroines and dramatic love stories, while the boys' favourite titles were mainly action thrillers. Kutay (2014) found that adventure (73.8\%) was the most chosen genre of fiction among the 10 categories provided. The next most preferred genre of fiction for females was romance (70\%), followed by horror (52\%). The most preferred genre of fiction for males was war-spy stories (56\%), followed by crime-detective (45\%). The results of various studies reveal that the literature reading habits of the students vary between genders and regions. Kulkarni, Dhanamjaya and Balaji (2017) found that the majority of the respondents agreed (46.1\%) and strongly agreed (33\%) that visiting literature festivals would influence or improve reading habits. 
A good number of studies have been conducted on reading habits on the general population in India. However, the present study was conducted on a unique population (adolescent students) from a different institution (Delhi Public School), different place (Jammu \& Kashmir) and with different objectives. Adolescence is a transitional stage of physical and psychological development that generally occurs during the period from puberty to legal adulthood. During adolescence, a person has different needs and tastes as compared to adulthood. Further, the Jammu and Kashmir state is a conflict zone and these students face many challenges in their educational pursuits. The daily political and armed incidents, and calls for strikes from separatist groups hinder their academic performance and make it difficult for them to compete with students of other states. Furthermore, the researchers studied not only the literature reading habits but also the authors' promotional tactics as well. Authors use various promotional tactics in the text to attract new or potential readers. The present study has analysed the impact of authors' tactics on the students' reading preferences.

\section{RESEARCH DESIGN}

This study sought to find out the literature reading habits and preferences of adolescent students, and the promotional tactics of authors to attract these students towards reading. It attempted to address following questions:

- RQ1. What are the reading habits of adolescents, in terms of:

o Avid versus occasional readers

o Time spent on reading

o Place and format preferences

o Selection of reading literature

- RQ2. What are the literature reading preferences:
o Fiction versus non-fiction
o Classic versus contemporary
o Different kinds of fiction
o Different kinds of non-fiction

- RQ3. What are the authorship preferences:

o Male versus female authors

o Indian versus foreign authors

- RQ4. Whether fiction is promoted by the use of:

o Aggression and violence

o More romantic content

o Explicit (sexual) content

o Slangs and crude language

- RQ5. What are the literature reading interests and opinions across genders?

The Delhi Public School (DPS) in Srinagar (in the Indian state of Jammu and Kashmir) was the location of the study. It is one of the best schools in the state in terms of the quality of education. The Delhi Public School is a co-educational senior secondary school established in 2003. The school is affiliated with the Delhi Public School Society and the Central Board of Secondary Education. The Delhi Public School Society has a chain of schools providing quality education at school level in India and abroad. The Delhi Public School is equipped with the modern educational facilities, including language labs, art studios, computing 
facilities and libraries. The school has five libraries with a rich collection of almost eighty thousand documents to cater to the information needs of students and teachers. These libraries are:

1. General Library

2. Reference Library (for 10 to 12th Standard students)

3. Tiny Tots Library (for up to 2nd Standard)

4. Special Education Needs (SEN) Library (for specially-abled students)

5. Knowledge Base (Digital Library).

The students of the Delhi Public School mostly come from the Kashmir province of the Jammu and Kashmir State, especially Srinagar (the summer capital of the state) and adjacent districts. However, the students of this school belong to the more highly educated families with good socio-economic backgrounds, which may have a big impact on the reading habits of students.

The data were collected in the Delhi Public School from the students of 11th and 12th classes (grades), falling in the age group of 14-16 years. The total cohort size for the 11th and 12th class students was $432.35 \%$ (150) were selected as sample using a systematic sampling method. The ratio of the boys and girls in the sample was 50:50. The questionnaire was used as the main data collection tool. Before designing the questionnaire, interactions were conducted with many students to gain insights of their literature reading habits, and to develop the questions and answer choices in the questionnaire. Later, a pilot study was conducted and the questionnaire was modified to avoid any ambiguities. The questionnaire (provided in the Appendix) was structured into five parts - personal information, reading habits, literature preferences, authorship preferences, and authors' promotional tactics.

\section{DATA ANALYSIS}

\section{Reading Habits}

\section{Avid versus occasional readers}

Pupils were asked to rate themselves on a scale of 1-10 (lowest to highest readers). Table 1 shows that the majority of the students were frequent readers as $67 \%$ of the students rated themselves in the range $6-10$ (65\% of boys and $69 \%$ of girls), whereas only $33 \%$ rated themselves in the range 1-5 (35\% of boys and 31\% of girls). This shows that pupils of both genders like reading, with a noticeable gender difference (almost 5\%). The findings are aligned with the results of earlier studies (e.g., McKenna, Kearn, \& Ellsworth, 1995; Clark \& Foster, 2005; Shafi \& Loan, 2010) who confirmed that females read more often than males.

\section{Time spent reading}

The time analysis shows that $91 \%$ of respondents spent less than 3 hours on reading daily, whereas just $9 \%$ of respondents ( $12 \%$ girls and $7 \%$ boys) spent 3 or more hours on reading per day. On average, a respondent spent 1.45 hours on reading daily: girls spent 1.54 hours, whereas boys spent 1.36 hours on reading daily. The findings are consistent with Hopper (2005), Loan (2010) and Shafi and Loan (2010), who also found that females spent more time on reading than males. 
Table 1.Frequent and occasional readers

\begin{tabular}{|c|c|c|c|c|c|c|c|}
\hline Rate & Readers & All & $\%$ & Boys & $\%$ & Girls & $\%$ \\
\hline 1 & \multirow{5}{*}{ 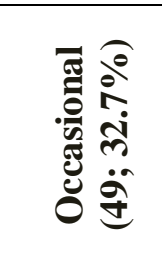 } & 0 & 0.0 & 0 & 0.0 & 0 & 0.0 \\
\hline 2 & & 3 & 2.0 & 2 & 2.7 & 1 & 1.3 \\
\hline 3 & & 10 & 6.7 & 4 & 5.3 & 6 & 8.0 \\
\hline 4 & & 12 & 8.0 & 5 & 6.7 & 7 & 9.3 \\
\hline 5 & & 24 & 16.0 & 15 & 20.0 & 9 & 12.0 \\
\hline 6 & \multirow{5}{*}{ 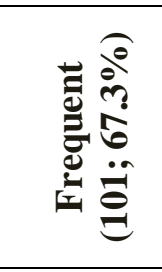 } & 14 & 9.3 & 9 & 12.0 & 5 & 6.7 \\
\hline 7 & & 22 & 14.7 & 12 & 16.0 & 10 & 13.3 \\
\hline 8 & & 30 & 20.0 & 12 & 16.0 & 18 & 24.0 \\
\hline 9 & & 23 & 15.3 & 10 & 13.3 & 13 & 17.3 \\
\hline \multirow[t]{2}{*}{10} & & 12 & 8.0 & 6 & 8.0 & 6 & 8.0 \\
\hline & & 150 & 100.0 & 75 & 100.0 & 75 & 100.0 \\
\hline
\end{tabular}

Table 2. Time spent on reading daily

\begin{tabular}{|c|c|c|c|c|c|c|c|}
\hline No. & Time spent & All & $\%$ & Boys & $\%$ & Girls & $\%$ \\
\hline 1 & $\leq 1$ hour & 38 & 25.3 & 23 & 30.7 & 15 & 20.0 \\
\hline 2 & 1-2 hours & 50 & 33.3 & 26 & 34.7 & 24 & 32.0 \\
\hline 3 & 2-3 hours & 48 & 32.0 & 21 & 28.0 & 27 & 36.0 \\
\hline 4 & $\geq 3$ hours & 14 & 9.3 & 5 & 6.7 & 9 & 12.0 \\
\hline \multicolumn{2}{|l|}{ Total } & 150 & 100.0 & 75 & 100.0 & 75 & 100.0 \\
\hline \multicolumn{2}{|c|}{ Total Time Spent } & \multicolumn{2}{|c|}{$\Sigma(\mathrm{a})=263$ hours } & \multicolumn{2}{|c|}{$\Sigma(\mathrm{b})=120.5$ hours } & \multicolumn{2}{|c|}{$\Sigma(\mathrm{g})=142.5$ hours } \\
\hline \multicolumn{2}{|c|}{ Average Time Spent } & \multicolumn{2}{|c|}{$\begin{array}{l}\text { Mean=1.75 } \\
\text { (i.e. } 1.45 \text { ) hours }\end{array}$} & \multicolumn{2}{|c|}{$\begin{array}{l}\text { Mean=1.60 } \\
\text { (i.e. 1.36) hours }\end{array}$} & \multicolumn{2}{|c|}{$\begin{array}{l}\text { Mean= } 1.90 \\
\text { (i.e.1.54) hours }\end{array}$} \\
\hline
\end{tabular}

\section{Favourite place}

The home is the favourite place for reading as the majority of students (64\%) preferred to read at home, followed by the library (20\%) and classroom (11\%), with notable gender differences. This finding was also consistent with the findings of the studies conducted by McKenna and Tan (2007) and Loan (2010).

\section{Favourite format}

The majority of adolescents (71\%) preferred to use print over digital formats (5.33\%). However, a good percentage preferred both print and digital formats (23\%) for reading. However, there was a small difference in format preferences across gender, as $68 \%$ of boys preferred the print in comparison to $75 \%$ of girls. 


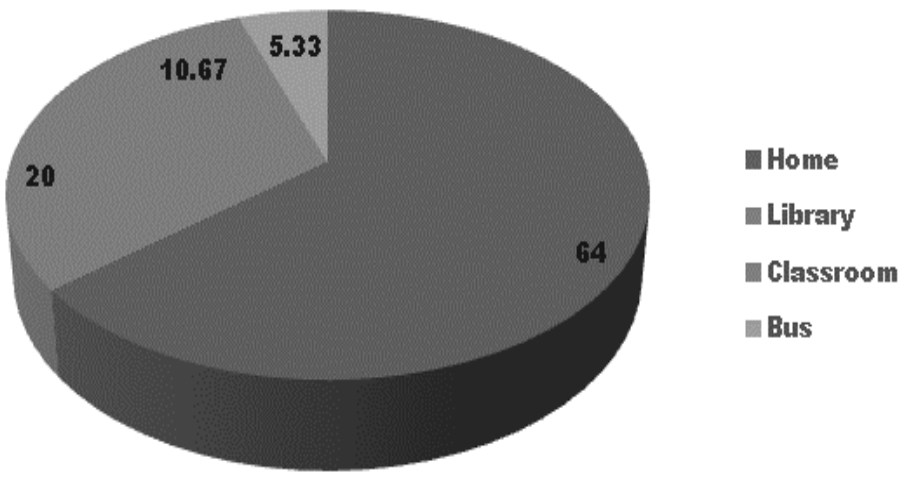

Figure 1. Favourite place for reading

\section{Means of selection}

The data indicates that $48 \%$ of the respondents ( $49 \%$ of boys and $47 \%$ of girls) read literature suggested by friends; $40 \%$ selected books from the Bestseller/Goodreads website (37\% of boys and $42 \%$ of girls) and $28 \%$ from library services (31\% of boys and $25 \%$ of girls). However, the respondents used other means to select books: reviews/blurbs (25\%), pick up randomly (21\%), online shopping portals (21\%), and others (21\%), with notable gender differences (see Table 4).

\section{Literature Preferences}

\section{Classic versus contemporary}

The results reveal that $42 \%$ (63) respondents preferred to read contemporary literature, whereas 35\% (53) preferred classic and 23\% (34) both. The gender wise data show that boys mostly preferred contemporary literature (34, 45\%) compared to classic $(25,33 \%)$, whereas girls preferred contemporary and classic almost equally (39\% versus 37\%). However, $21 \%$ of boys and $24 \%$ of girls preferred to read classic as well as contemporary literature (Figure 2).

\section{Fiction versus non-fiction}

Fiction is the most preferred type of literature read by $47 \%$ of the respondents, followed by non-fiction (32\%). In terms of gender preferences, a greater percentage of girls (51\%) preferred fiction to boys (43\%). Similarly, more boys (39\%) preferred non-fiction to girls (25\%). However, 21\% preferred both types of literature (fiction and non-fiction), in which girls (24\%) surpass boys (18.67\%) (see Table 5).

\section{Fiction preferences}

Among the various categories of fiction, crime detective (31\%) is the most read literature, followed by realistic teen fiction (21\%). Poetry (5\%) is the least read. Gender analysis of the data also indicates the same trend; however, romance and poetry were more popular among girls whereas crime detective, horror and realistic teen fiction were more popular among boys (see Table 6). 
Table 3. Format preferences

\begin{tabular}{r|l|rc|rr|rr}
\hline & & & & & & & \\
No. & Format & All & \% & Boys & $\mathbf{\%}$ & Girls & \% \\
\hline & Digital/ & & & & & & \\
1 & Online & 8 & 5.3 & 5 & 6.7 & 3 & 4.0 \\
2 & Printed & 107 & 71.3 & 51 & 68.0 & 56 & 74.7 \\
3 & Both & 35 & 23.3 & 19 & 25.3 & 16 & 21.3 \\
\hline & & $\mathbf{1 5 0}$ & $\mathbf{1 0 0 . 0}$ & $\mathbf{7 5}$ & $\mathbf{1 0 0 . 0}$ & $\mathbf{7 5}$ & $\mathbf{1 0 0 . 0}$ \\
\hline
\end{tabular}

Table 4. Means of selecting literature

\begin{tabular}{|c|c|c|c|c|c|c|c|}
\hline No. & Selection Tactics & All & $\%$ & Boys & $\%$ & Girls & $\%$ \\
\hline 1. & $\begin{array}{l}\text { Suggested by } \\
\text { friends }\end{array}$ & 72 & 48.0 & 37 & 49.3 & 35 & 46.7 \\
\hline 2. & Pick randomly & 32 & 21.3 & 17 & 22.7 & 15 & 20.0 \\
\hline 3. & Reviews/Blurbs & 38 & 25.3 & 18 & 24.0 & 20 & 26.7 \\
\hline 4. & $\begin{array}{l}\text { Library services } \\
\text { Online portals }\end{array}$ & 42 & 28.0 & 23 & 30.7 & 19 & 25.3 \\
\hline 5. & $\begin{array}{l}\text { (Shopping) } \\
\text { Bestseller/ }\end{array}$ & 31 & 20.7 & 18 & 24.0 & 13 & 17.3 \\
\hline 6. & Goodreads lists & 60 & 40.0 & 28 & 37.3 & 32 & 42.7 \\
\hline 7. & Others & 31 & 20.7 & 12 & 16.0 & 19 & 25.3 \\
\hline
\end{tabular}

Note:Respondents can select more than one option

\section{Non-fiction preferences}

For non-fiction, the highest proportion of respondents read self-help/personality development books (43\%), followed by biographies or autobiographies (33\%) and historical books (25\%). Boys preferred to read biographies or autobiographies (37\%), followed by selfhelp/personality development (33\%) and historical books (29\%), whereas girls preferred selfhelp/personality development (52\%), followed by biographies or autobiographies (28\%) and historical books (20\%). Boys mostly preferred to read personalities whereas selfhelp/personality development was the first preference of girls (see Table 7).

\section{Authorship preferences}

Male versus female authors

It has been observed that an author's gender doesn't affect reading interests, as $77 \%$ of the respondents read the literature of both genders. However, $12 \%$ preferred literature written by males and $11 \%$ written by females. Gender analysis indicates the same trend with little difference between different genders (see Table 8). 


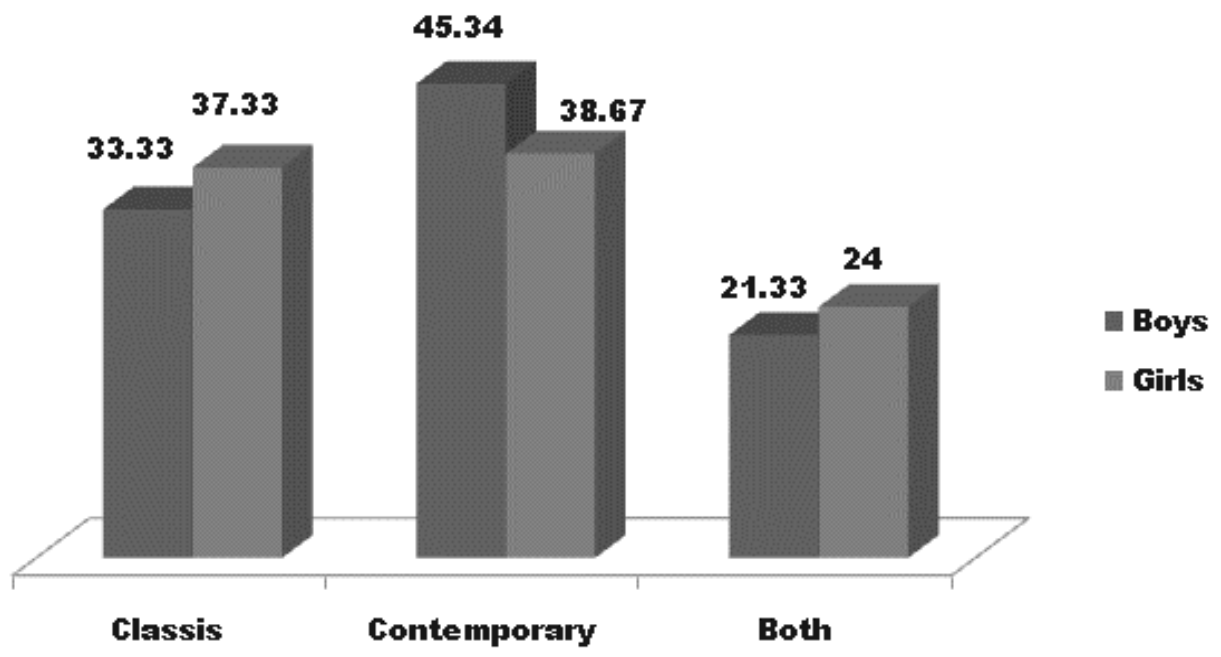

Figure 2. Classic versus contemporary

\section{Indian Versus Foreign Authors}

It is clear that the nationality of an author affects reading choices to some extent as only $54 \%$ preferred to read both Indian as well as foreign authors, whereas 29\% preferred to read foreign authors. 17\%preferred Indian authors. The results reveal that more girls preferred Indian authors to boys (20\% versus $13 \%$ ), and foreign authors were equally preferred by boys and girls (see Table 9).

\section{Authors' Promotional Tactics}

Authors use various tactics in their writings (literature) to attract adolescents, which include aggression and violence, romantic language, explicit content (sexuality), and slang/crude language. The 5-point Likert scale was used to assess the opinions of readers regarding such tactics employed by authors.

\section{Aggression and violence}

$39 \%$ of the respondents either disagreed (21\%) or strongly disagreed (19\%) that authors used "aggression and violence" to promote their content, whereas 32\% either agreed (23\%) or strongly agreed (9\%) on the issue. More girls (36\%) than boys (28\%) agreed/strongly agreed that authors used these tactics to promote their content, and both genders showed disagreement with the opinion with a slight gender difference. A good number of respondents (29\%) gave a neutral response, with a higher proportion of boys (32\%) than girls (25\%) (see Table 10.)

\section{Romantic language}

$25 \%$ of the respondents agreed and $16 \%$ strongly agreed that romantic language is a tactic used by authors for promotional purposes. The gender-specific analysis shows that more boys agreed (28\% versus $23 \%$ ) with the argument than girls (see Table 11.$)$ 
Table 5: Fiction versus non-fiction

\begin{tabular}{c|l|cc|cc|cc}
\hline & & & & & & & \\
No. & Literature & All & \% & Boys & \% & Girls & \% \\
\hline 1 & Fiction & 70 & 46.7 & 32 & 42.7 & 38 & 50.7 \\
2 & Non-fiction & 48 & 32.0 & 29 & 38.7 & 19 & 25.3 \\
3 & Both & 32 & 21.3 & 14 & 18.7 & 18 & 24.0 \\
\hline & & $\mathbf{1 5 0}$ & $\mathbf{1 0 0 . 0}$ & $\mathbf{7 5}$ & $\mathbf{1 0 0 . 0}$ & $\mathbf{7 5}$ & $\mathbf{1 0 0 . 0}$ \\
\hline
\end{tabular}

Table 6.Fiction preferences

\begin{tabular}{c|l|rr|rr|rr}
\hline No. & Fiction preferences & All & \% & Boys & \% & Girls & \% \\
\hline 1 & Mystery thriller & 26 & 17.3 & 13 & 17.3 & 13 & 17.3 \\
2 & Horror & 13 & 8.7 & 8 & 10.7 & 5 & 6.7 \\
3 & Crime detective & 47 & 31.3 & 25 & 33.3 & 22 & 29.3 \\
4 & Romance & 26 & 17.3 & 9 & 12.0 & 17 & 22.7 \\
5 & Poetry & 7 & 4.7 & 3 & 4.0 & 4 & 5.3 \\
6 & Realistic teen fiction & 31 & 20.7 & 17 & 22.7 & 14 & 18.7 \\
\hline & Total & $\mathbf{1 5 0}$ & $\mathbf{1 0 0 . 0}$ & $\mathbf{7 5}$ & $\mathbf{1 0 0 . 0}$ & $\mathbf{7 5}$ & $\mathbf{1 0 0 . 0}$ \\
\hline
\end{tabular}

Table 7. Non-fiction preferences

\begin{tabular}{|c|c|c|c|c|c|c|c|}
\hline No. & $\begin{array}{l}\text { Non-fiction } \\
\text { preferences }\end{array}$ & All & $\%$ & Boys & $\%$ & Girls & $\%$ \\
\hline 1 & Historical & 37 & 24.6 & 22 & 29.3 & 15 & 20.0 \\
\hline 2 & Self-Help/Personality & & & & & & \\
\hline \multirow{3}{*}{3} & Development & 64 & 42.7 & 25 & 33.3 & 39 & 52.0 \\
\hline & $\begin{array}{l}\text { (Biographies/ } \\
\text { autobiographies) }\end{array}$ & 49 & 32.7 & 28 & 37.3 & 21 & 28.0 \\
\hline & Total & 150 & 100.0 & 75 & 100.0 & 75 & 100.0 \\
\hline
\end{tabular}

Table 8. Gender authorship preferences

\begin{tabular}{r|l|rc|rc|rc}
\hline No. & $\begin{array}{l}\text { Authors' } \\
\text { gender }\end{array}$ & All & $\mathbf{\%}$ & Boys & \% & Girls & \% \\
\hline & Male & 18 & 12.0 & 8 & 10.7 & 10 & 13.3 \\
2 & Female & 17 & 11.3 & 9 & 12.0 & 8 & 10.7 \\
3 & Both & 115 & 76.7 & 58 & 77.3 & 57 & 76.0 \\
\hline & & $\mathbf{1 5 0}$ & $\mathbf{1 0 0 . 0}$ & $\mathbf{7 5}$ & $\mathbf{1 0 0 . 0}$ & $\mathbf{7 5}$ & $\mathbf{1 0 0 . 0}$ \\
\hline
\end{tabular}


Table 9. Nationality authorship preferences

\begin{tabular}{l|l|rc|cc|cr}
\hline & $\begin{array}{l}\text { Authors' } \\
\text { No }\end{array}$ & Origin & All & $\mathbf{\%}$ & Boys & \% & \multicolumn{2}{|c}{ Girls \% } \\
\hline 1 & Indian & 25 & 16.7 & 10 & 13.3 & 15 & 20.0 \\
2 & Foreign & 44 & 29.3 & 22 & 29.3 & 22 & 29.3 \\
3 & Both & 81 & 54.0 & 43 & 57.3 & 38 & 50.7 \\
\hline & & $\mathbf{1 5 0}$ & $\mathbf{1 0 0 . 0}$ & $\mathbf{7 5}$ & $\mathbf{1 0 0 . 0}$ & $\mathbf{7 5}$ & $\mathbf{1 0 0 . 0}$ \\
\hline
\end{tabular}

Table 10. Use of aggression and violence

\begin{tabular}{l|l|rr|rr|rr}
\hline No. & $\begin{array}{l}\text { Use of aggression } \\
\text { and violence }\end{array}$ & All & $\mathbf{\%}$ & Boys & \% & Girls & \% \\
\hline 1 & Strongly disagree & 28 & 18.7 & 15 & 20.0 & 13 & 17.4 \\
2 & Disagree & 31 & 20.7 & 15 & 20.0 & 16 & 21.3 \\
3 & Neutral & 43 & 28.7 & 24 & 32.0 & 19 & 25.3 \\
4 & Agree & 35 & 23.3 & 15 & 20.0 & 20 & 26.7 \\
5 & Strongly agree & 13 & 8.6 & 6 & 8.0 & 7 & 9.3 \\
\hline & & $\mathbf{1 5 0}$ & $\mathbf{1 0 0 . 0}$ & $\mathbf{7 5}$ & $\mathbf{1 0 0 . 0}$ & $\mathbf{7 5}$ & $\mathbf{1 0 0 . 0}$ \\
\hline
\end{tabular}

Table 11. Use of romantic language

\begin{tabular}{c|l|rr|rr|rr}
\hline No. & $\begin{array}{l}\text { Use of romantic } \\
\text { language }\end{array}$ & All & \% & Boys & \% & Girls & \% \\
\hline 1 & Strongly disagree & 15 & 10.0 & 8 & 10.7 & 7 & 9.3 \\
2 & Disagree & 23 & 15.3 & 10 & 13.3 & 13 & 17.3 \\
3 & Neutral & 50 & 33.3 & 24 & 32.0 & 26 & 34.7 \\
4 & Agree & 38 & 25.3 & 21 & 28.0 & 17 & 22.7 \\
5 & Strongly agree & 24 & 16.0 & 12 & 16.0 & 12 & 16.0 \\
\hline & & $\mathbf{1 5 0}$ & $\mathbf{1 0 0 . 0}$ & $\mathbf{7 5}$ & $\mathbf{1 0 0 . 0}$ & $\mathbf{7 5}$ & $\mathbf{1 0 0 . 0}$ \\
\hline
\end{tabular}

Table 12. Use of explicit content (sexuality)

\begin{tabular}{|c|c|c|c|c|c|c|c|}
\hline No. & $\begin{array}{l}\text { Use of explicit } \\
\text { content/sexuality }\end{array}$ & All & $\%$ & Boys & $\%$ & Girls & $\%$ \\
\hline 1 & Strongly disagree & 29 & 19.3 & 15 & 20.0 & 14 & 18.7 \\
\hline 2 & Disagree & 38 & 25.3 & 20 & 26.7 & 18 & 24.0 \\
\hline 3 & Neutral & 40 & 26.7 & 20 & 26.7 & 20 & 26.7 \\
\hline 4 & Agree & 25 & 16.7 & 11 & 14.6 & 14 & 18.7 \\
\hline \multirow[t]{2}{*}{5} & Strongly agree & 18 & 12.0 & 9 & 12.0 & 9 & 12.0 \\
\hline & & 150 & 100.0 & 75 & 100.0 & 75 & 100.0 \\
\hline
\end{tabular}


Table 13. Usage of slang/crude language

\begin{tabular}{|c|c|c|c|c|c|c|c|}
\hline No. & $\begin{array}{l}\text { Use of slang } \\
\text { \&crude language }\end{array}$ & All & $\%$ & Boys & $\%$ & Girls & $\%$ \\
\hline 1 & Strongly disagree & 18 & 12.0 & 11 & 14.7 & 7 & 9.3 \\
\hline 2 & Disagree & 23 & 15.3 & 11 & 14.7 & 12 & 16.0 \\
\hline 3 & Neutral & 55 & 36.7 & 28 & 37.3 & 27 & 36.0 \\
\hline 4 & Agree & 39 & 26.0 & 18 & 24.0 & 21 & 28.0 \\
\hline \multirow[t]{2}{*}{5} & Strongly agree & 15 & 10.0 & 7 & 9.3 & 8 & 10.7 \\
\hline & & 150 & 100.0 & 75 & 100.0 & 75 & 100.0 \\
\hline
\end{tabular}

\section{Explicit content (Sexuality)}

Authors' use of explicit content (sexuality) to attract readers was not subscribed to by $45 \%$ of the respondents, whereas only $29 \%$ believed so, albeit with a slight gender difference. However, an equal proportion of boys as well as girls (27\%) were neutral (see Table 12).

\section{Use of slang and crude language}

$36 \%$ of the respondents either agreed or strongly agreed with the statement that "authors use slang and crude language to attract readers", with a noticeable gender difference (39\% of girls and $33 \%$ of boys). However, $27 \%$ of the respondents (29\% of boys and $25 \%$ of girls) did not support the statement (see Table 13.)

\section{DISCUSSION}

The study has found that adolescents of both genders like reading on electronic media, with a small gender difference (69\% of girls and 65\% of boys). Loan (2011b) had argued that the reading habit will survive in the present media mix. The preferences and tastes of the present (net) generation can change, but reading will continue to maintain its unique and indispensable position alongside electronic media. However, almost one-third of students do not have positive attitudes towards reading. "[A] Reading habit is best formed at a young impressionable age in school, but once formed it can last one's life time” (Greene, 2001). It is, therefore, the duty of parents, teachers, and librarians to help inculcate a reading habit in children at an early age. Librarians need to build a strong literature collection in libraries, acquiring the Bestsellers/Goodreads collection and autobiographies/biographies of reputed personalities for students' intellectual and moral development.

Adolescents have varied literature reading tastes. Fiction is the most preferred type of literature, followed by non-fiction. However, more girls than boys prefer fiction, and more boys than girls prefer non-fiction. Among the various genres of fiction, crime detective is the most read genre followed by realistic teen fiction. Romance and poetry are more popular among girls, whereas crime detective, horror, and realistic teen fiction are more popular among boys. For non-fiction, a high proportion of the respondents read self-help/personality development books, followed by biographies/autobiographies and historical books. Boys mostly prefer to read about personalities, whereas self-help/personality development is the first preference of girls. When preferences for contemporary and classic literature are analyzed, the results reveal that contemporary literature is preferred more than classic, across both genders. It has been observed that an author's gender does not affect the reading choices. 
However, the author's nationality affects the reading choices to some extent, as more respondents prefer to read foreign authors compared to Indian authors, with small gender differences. A good percentage of adolescents also indicated that the gender and nationality of authors did not affect their reading choices.

Authors use various tactics in their writings to attract readers, especially aggression and violence, romantic language, explicit content (sexuality), and slang/crude language. One-third of the responses are positive in this case. The argument that romantic language is a tactic used by authors for promotional purposes is agreed and strongly agreed with by more than $40 \%$ of the respondents, whereas “Authors use explicit content (sexuality) to attract readers” was not subscribed to by the majority of respondents. The general observation is that author tactics show positive signs in attracting some percentage of readers. However, while using these tactics to attract users, authors need to impart the message in a logical and reasonable way without compromising moral principles of writing and education in relation to adolescent readers.

The present study was conducted with a small sample size of 150 students, and a small number of variables were studied. A larger-scale study is needed to study the trends in literature reading at the state or national level.

\section{REFERENCES}

Abdul Karim, N.S., \& Hasan, A. (2007). Reading habits and attitude in the digital age: Analysis of gender and academic program differences in Malaysia. The Electronic Library, 25(3), 285-298.

Adams, M.J. (1990). Beginning to read: Thinking and learning about print. Cambridge, MA: MIT Press.

Addison, J., \& Steele, R. (1899). [Article in The Tatler, no. 147, March 16-18, 1710]. Republished in G.A. Aitken (Ed.), The Tatler, Volume 3 (p. 175). New York: Hadley \& Mathews. Available from: http://www.gutenberg.org/ebooks/31645

Cabral, A.P., \& Tavares, J. (2002). Practising college reading strategies. The Reading Matrix, 2(3), 1-16.

Cipielewski, J., \&Stanovich, K.E. (1992). Predicting growth in reading ability from children's exposure to print.Journal of Experimental Child Psychology, 54, 75-89.

Clark, C., \& Akerman, R. (2006). Social inclusion and reading — an exploration. London: National Literacy Trust.

Clark, C., \& Foster, A. (2005). Children's and young people's reading habits and preferences: The who, what, why, where and when. Retrieved from www.literacytrust.org.uk/Research/Reading_Connects_survey.pdf

Clark, C. (2012). Children's and young people's reading today: Findings from the 2011 National Literacy Trust's annual survey. London: National Literacy Trust.

Cox, K.E., \& Guthrie, J.T. (2001). Motivational and cognitive contributions to students' amount of reading. Contemporary Educational Psychology, 26(1), 116-131.

Cunningham, A.E., \& Stanovich, K.E. (1998). What reading does for the mind? American Educator, 22, 8-15.

De Boer, J.J., \& Dall Mann, M. (1960). The teaching of reading. NewYork: Holt, Rinehart and Winston.

Department of Education, Hong Kong (2001). Survey on the reading habits of students in Hong Kong. Retrieved from http://www.edb.gov.hk/filemanager/en/content_691/p0102e.PDF 
Devarajan, G. (1989). Reading interests of secondary school students. In Users approach to information in libraries (p. 14). New Delhi: Ess Ess.

Elizabeth, H. (2009). Good reads: Quotes by Elizabeth Hardwick. Retrieved from http://www.goodreads.com/author/quotes /5268.Elizabeth_Hardwick

Gray, B.L., \& Tinker, M.A. (1967). Reading difficulties: Their diagnosis and correction (2nd ed.). New York: Appleton Century-Crofts.

Greene, B. (2001).Testing reading comprehension of theoretical discourse with Cloze. Journal of Research in Reading, 24(1), 32-98.

Guthrie, J.T., Wigfield, A., Metsala, J., \& Cox, K. (1999). Motivational and cognitive predictors of text comprehension and reading amount. Scientific Studies of Reading, 3, 231-256.

Hassell, S.H., \& Rodge, P. (2007).The leisure reading habits of urban adolescents. Journal of Adolescent and Adult Literacy, 51(1), 22-33.

Hastings, C., \& Henry, J. (2006, July 23). Reading is a closed book to today's children. The Telegraph. Retrieved from http://www.telegraph.co.uk/news/1524595/Reading-is-aclosed-book-totoday's-children.html

Hopper, R. (2005). What are teenagers reading? Adolescent fiction reading habits and reading choices. Literacy, 39(3), 113-120.

Igun, S.E., \& Adogbeji, O.B. (2007). Study habits of postgraduate students in selected Nigerian universities. Library Philosophy and Practice, 2007. Retrieved from http://www. webpages.uidaho.edu/ mbolin/igun-adogbeji.pdf

Kendrick, J.M. (1999). Middle grade boys: Reading habits and preferences for a new millennium. Retrieved from https://eric.ed.gov/?id=ED429274

Kulkarni, S., Dhanamjaya, M., \& Balaji, B.P. (2017). Do literature festivals promote reading and public libraries? A survey. Library Hi Tech News, 34(2), 13-15. doi: https://doi.org/10.1108/LHTN-02-2017-0007

Kutay, V. (2014). A survey of the reading habits of Turkish high school students and an examination of the efforts to encourage them to read (Unpublished Ph.D. thesis). University of Loughborough, United Kingdom. Retrieved from https://dspace.lboro.ac.uk/dspace-jspui/bitstream/2134/15786/3/Thesis-2014-Kutay.pdf

Loan, F.A. (2010). Impact of surfing on reading habits: A case study of the students of Kashmir Valley (Unpublished $\mathrm{PhD}$ thesis). University of Kashmir, India.

Loan, F.A. (2011a). Reading and library usage habits of the college students. International Journal of Information Research, 1(1), 1-13. Retrieved from http://www.spoars.org/journal/sites/default/files/v1n1p7.pdf

Loan, F.A. (2011b). Media preferences of the net generation college students. International Journal of Library and Information Science, 3(7), 155-161.

Loan, F.A. (2012). Impact of the Internet surfing on reading practices and choices. Webology, 9(1), article 94. Retrieved from: http://www.webology.org/2012/v9n1/a94.html

Lone, F.A. (2011).Reading habits of rural and urban college students in the 21st century. Library Philosophy and Practice, 2011. Retrieved from http://digitalcommons.unl.edu/cgi/viewcontent.cgi?article=1617\&context=libphilprac

Lone, F.A. (2011, April 23). The power of reading. Greater Kashmir. Retrieved from http://www.greaterkashmir.com/news/gk-magazine/the-power-of-reading/93365.html

Majid, S., \& Tan, V. (2007).Understanding the reading habits of children in Singapore. Journal of Education Media \& Library Sciences, 45(2), 187-198. Retrieved from http://joemls.tku.edu.tw/45/45-2/187-198.pdf 
McKenna, M., Kear, D., \& Ellsworth, R. (1995). Children’s attitudes toward reading: A national survey. Reading Research Quarterly, 30, 934-95.

Mellon, C.A. (1990). Leisure reading choices of rural teens. School Library Media Quarterly. $18,223-228$.

Moyes, J. (2000, May 18). Idea that Net is killing book reading can be filed under fiction. The Independent. Retrieved fromhttp://www.independent.co.uk/artsentertainment/books/news/idea-that-net-iskilling-book-reading-can-be-filed-underfiction-718166.html

Nagy, W.E., Herman, P.A., \& Anderson, R.C. (1985). Learning words from context. Reading Research Quarterly, 20, 233-253.

Norvell, G.W. (1973). The reading interests of young people. East Lansing: Michigan State University Press.

Robinson, R., \& Good, T.L. (1987). Becoming an effective reading teacher. New York: Harper and Row.

Ross, C.S. (2002). Reading in a digital age. In G.E. Gorman (Ed.), The digital factor in library and information services (pp. 91-111). London: Facet.

Salim, S. (2009). Seven ways to improve your reading habit. Retrieved November23, 2016 from http://ezinearticles.com/?Seven-Ways-to-Improve-Your-ReadingHabit\&id=2818377

Satija, M.P. (2002). Reading and book culture. Herald of Library Science, 41(1/2), 55-59.

Shafi, S.M., \& Loan, F.A. (2010). Reading habits among college students of Kashmir across genders. Trends in Information Management, 6(2), 92-103.

Sheorey, R., \& Mokhtari, K. (1994). The reading habits of developmental college students at different levels of reading proficiency. Reading Improvement, 31(3), 156-166.

Shokeen, A. (2005). Promoting a love for reading. ILA Bulletin, 41(1), 5-9.

Stenberg, C. (2001). Reading research in Sweden-a short survey. In 67th IFLA Council and General Conference, August 16-25, 2001, Boston. Retrieved from http://archive.ifla.org/IV/ifla67/papers/181-113e.pdf

Taylor, B.M., Frye, B.J., \& Maruyama, G.M. (1990). Time spent reading and reading growth. American Educational Research Journal, 27, 351-362.

Teale, W.H., \& Martinez, M.G. (1988). Getting on the right road to reading: Bringing books and young children together in the classroom. Young Children, 44(1), 10-15.

Tella, A., \& Akande, S. (2007). Children reading habits and availability of books in Botswana primary schools: Implications for achieving quality education. The Reading Matrix, 7(2), 117-142.

Tveit, A.K. (2012). Reading habits and library use among young adults. Review of Children's Literature and Librarianship, 18(2), 85-104. doi:10.1080/13614541.2012.714341

Vakkari, P., \& Serola, S. (2012). Perceived outcomes of public libraries. Library \& Information Science Research, 34, 37-44.

Walia, P.K., \& Sinha, N. (2014). Changing trend in reading habits of teenagers in Delhi: An impact assessment of demographic and environmental variables. Library Review, 63(1/2), 125-137. https://doi.org/10.1108/LR-03-2013-0038

Wicks, J. (1995). Patterns of reading among teenage boys: the reading habits and book preferences of 13-15-year-old boys. New Library World, 96(5), 10-16.

Yopp, R.H., \& Yopp, H.K. (2003). Time with text. The Reading Teacher, 57(3), 28. 


\section{APPENDIX. QUESTIONNAIRE}

\section{Reading Habits}

1.1. Rate yourself according to your reading habit.

$\begin{array}{llllllllll}1 & 2 & 3 & 4 & 5 & 6 & 7 & 8 & 9 & 10\end{array}$

(On the scale of $1-10 ; 10$ being the most avid reader

1.2. How much time you spend daily in reading literature?
a) $\leq 1$ hour
b) 1-2 hours
c) 2-3 hours
d) $\geq 3$ hours

1.3. Where do you prefer to read books?
a) Home
b) Library
c) Classroom
d) Other

1.4. In which format do you prefer to read?
a) Digital/online
b) Printed
c) Both

1.5. How do you select reading material?

\begin{tabular}{|l|l|l|}
\hline & \multicolumn{1}{|c|}{ Means of Selection } & Tick \\
\hline a) & Suggested by friends & \\
\hline b) & Library Services & \\
\hline c) & Reviews \& Blurbs & \\
\hline d) & Bestseller/ Good Reads lists & \\
\hline e) & Online portals (Shopping) & \\
\hline f) & Pick Randomly & \\
\hline g) & Other means & \\
\hline
\end{tabular}

\section{Literature Reading}

2.1. Which genre do you prefer to read?
a) Classic literature
b) Contemporary literature
c) Both

2.2. What literature do you prefer to read?
a) Fiction
b) Non-fiction
c) Both

2.3. What do you read most in Fiction?
a) Mystery/Thriller
b) Horror
c) Crime detective
d) Romance
e) Poetry
f) Realistic teenage fiction

2.4. What do you read most in Non-fiction?
a) Historical
b) Self help/Personality development
c) Personalities/Biographies/Autobiographies 


\section{Author preferences}

3.1. I read literature written by authors.
a) Male
b) Female
c) Both

3.2. I read literature written by authors.
a) Indian
b) Foreign
c) Both

\section{Authors Promotional Tactics}

4.1. Do you think authors use these tactics to promote their writings?

\begin{tabular}{|l|l|l|l|l|l|}
\hline Promotional Tactics & $\begin{array}{l}\text { Strongly } \\
\text { Disagree }\end{array}$ & Disagree & Neutral & Agree & $\begin{array}{l}\text { Strongly } \\
\text { Agree }\end{array}$ \\
\hline $\begin{array}{l}\text { Use of Aggression and Violence } \\
\text { Use of Romantic Language }\end{array}$ & & & & & \\
\hline $\begin{array}{l}\text { Use of Explicit } \\
\text { Content/Sexuality }\end{array}$ & & & & & \\
\hline $\begin{array}{l}\text { Use of Slangs and Crude } \\
\text { Language }\end{array}$ & & & & & \\
\hline
\end{tabular}
Your Gender:
a) Male
b) Female
c) Third Gender

Age: Years

Thanks for your response 